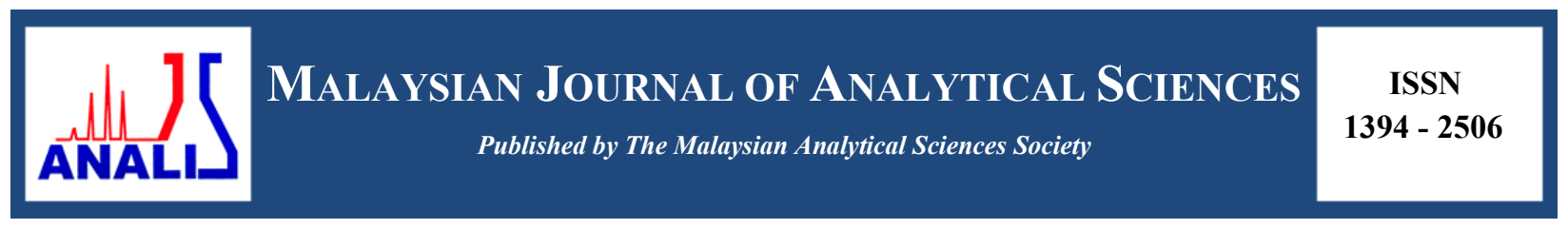

\title{
PHYSICOCHEMICAL PROPERTIES OF ENCAPSULATED PURPLE SWEET POTATO EXTRACT; EFFECT OF MALTODEXTRIN CONCENTRATION, AND MICROWAVE DRYING POWER
}

\author{
(Sifat Fizikokimia Ekstrak Keledek Ungu yang Dikapsul; Kesan Kepekatan Maltodekstrin, dan \\ Kuasa Pengeringan Gelombang Mikro) \\ Alyani Mohd Padzil ${ }^{1 *}$, Azni A. Aziz ${ }^{1}$, Ida Idayu Muhamad ${ }^{1,2}$ \\ ${ }^{I}$ Bioprocess and Polymer Engineering Department, Faculty of Chemical and Energy Engineering \\ ${ }^{2} I J N-U T M$ Cardiovascular Engineering Center Level 2, Block B, Building V01, Faculty of Biomedical Engineering \\ Universiti Teknologi Malaysia, 81310 Johor Bahru, Johor, Malaysia. \\ *Corresponding author: mpr.alyani@gmail.com
}

Received: 16 April 2017; Accepted: 7 March 2018

\begin{abstract}
Purple sweet potato (PSP) is rich with anthocyanin and has a great potential as natural food colorant. In this study, investigation on the effect of maltodextrin (MD, DE 4.0-7.0) concentration as wall material and various microwave drying powers towards physicochemical properties of microwave assisted encapsulation of purple sweet potato extract (PSPE) has been conducted. The effects of microwave power $(550 \mathrm{~W}$ and $330 \mathrm{~W})$ and $\mathrm{MD}$ concentration $(20 \%, 25 \%$, and $30 \%)$ were analysed for moisture content, water activity, colour, and total monomeric anthocyanin content (TMA). Both moisture content and water activity of the encapsulated PSPE were significantly decreased $(\mathrm{p}<0.05)$ as the MD concentration increased at $20 \%$ and $30 \%$. With respect of anthocyanin content, increasing of MD concentration at $20 \%$ and $30 \%$ showed a statistically significant reduction $(\mathrm{p}<0.05)$. PSPA with $20 \%$ concentration gave the highest TMA at both microwave drying power of $330 \mathrm{~W}$ and $550 \mathrm{~W}$, with $385.93 \pm 10.81$ $\mathrm{mg} / \mathrm{L}$ and $419.28 \pm 10.89 \mathrm{mg} / \mathrm{L}$ respectively. However, moisture content, water activity, colour, and TMA were not significantly different with the changing of microwave drying power.
\end{abstract}

Keywords: purple sweet potato, anthocyanin, microwave-assisted encapsulation, natural colorants, maltodextrin

\section{Abstrak}

Ubi keledek ungu (PSP) kaya dengan antosianin dan berpotensi untuk digunakan sebagai pewarna makanan semula jadi. Dalam kajian ini, kajian tentang kesan kepekatan maltodekstrin (MD, DE 4,0-7,0) sebagai bahan pengkapsulan dan pelbagai kuasa gelombang mikro pengeringan terhadap sifat fizikokimia ekstrak keledek ungu yang dikapsul telah dijalankan. Kesan kuasa gelombang mikro pengeringan $(550 \mathrm{~W}$ dan $330 \mathrm{~W})$ dan kepekatan maltodekstrin (MD) $(20 \%$, 25\%, dan $30 \%)$ dianalisis untuk kandungan kelembapan, aktiviti air, warna, dan jumlah kandungan antosianin monomerik (TMA). Nilai kandungan kelembapan dan aktiviti air daripada ektsrak keledek ungu yang dikapsulkan ketara berkurangan $(\mathrm{p}<0.05)$ dengan peningkatan kepekatan MD pada 20\% dan 30\%. Peningkatan kepekatan MD pada 20\% dan 30\% menunjukkan pengurangan TMA secara signifikan (p $<0.05$ ). PSPA dengan $20 \%$ kepekatan MD menunjukkan kandungan tertinggi TMA pada kedua-dua kuasa pengeringan ketuhar mikro $330 \mathrm{~W}$ dan $550 \mathrm{~W}$, dengan masing-masing $38593 \pm 10.81 \mathrm{mg} / \mathrm{L}$ dan $41928 \pm 10.89 \mathrm{mg} / \mathrm{L}$. Walau bagaimanapun, kandungan kelembapan, aktiviti air, warna, dan kandungan TMA tidak berbeza signifikan dengan perubahan kuasa pengeringan ketuhar gelombang mikro.

Kata kunci: keledek ungu, antosianin, pengkapsulan dengan bantuan gelombang mikro, pewarna semulajadi, maltodekstrin 


\section{Alyani et al: PHYSICOCHEMICAL PROPERTIES OF ENCAPSULATED PURPLE SWEET POTATO EXTRACT; EFFECT OF MALTODEXTRIN CONCENTRATION, AND MICROWAVE DRYING POWER}

\section{Introduction}

Natural food colorants are derived into agricultural, biological, or mineral sources. They have a simple extraction process and long history of safe usage. Some of synthetic colours have a natural equivalent, although their substitute may vary with the application. Many researches claimed that synthetic colours and additives might affect human health. Eliminating or substituting synthetic colours as colorants, food and beverage industry can choose a wide array of natural alternatives. Independently, natural colours do not have the same colour intensity as synthetic, and some are less economical on a dosage basis. However, this performance gap has been reduced due to the research and development (R\&D) initiatives. Furthermore, there are advantages in using natural colour. The side benefits such as natural antioxidant and sweetener can be carried out together during processing.

Purple Sweet Potato (PSP) was among the potential anthocyanin natural sources. PSP also known to have intense colour due to the high content of anthocyanin [1]. Research has been conducted on Ipomoea batatas also known as purple sweet potato (PSP) on its monomeric anthocyanin stability towards $\mathrm{pH}$ changes $(\mathrm{pH} 2.0,2.5,3.0,3.5,4.0$ and 4.5) compared with $H$. sabdariffa (roselle), and M. malabathricum [2]. Results showed that PSP was not affected at all while roselle and $M$. malabathricum were slightly affected by $\mathrm{pH}$ and quite stable up to $\mathrm{pH} 4.5$ due to its flexibility colour changing towards the $\mathrm{pH}$ value. They reported that; it could be used as a diagnostic device for detection of food spoilage. The stability of PSP anthocyanin also depends on temperature and solvent matrix [3]. Purple sweet potatoes are not the only food colourant. Choi et al. [4] had studied the development of a colometric $\mathrm{pH}$ indicator film packaging using colorant extracted from purple sweet potato.

Microwave is known as a common source of food heating. It also becomes an alternative drying method since it offers a shorter drying time and could improve the quality of a product [5]. Mohd Nawi et al. [6] agreed that microwave-assisted encapsulation can be categorised as an economical method for drying of natural colorant. Microwave-assisted encapsulation efficiency and product quality could be affected by several factors. Many studies proved that microwave drying capability is significantly affected by power variable [7]. Moreover, Zaidel et al. [5] showed that an optimum drying time is important to control the encapsulation process and prevent from degradation of anthocyanin content.

Encapsulation functions to coat an active compound or acts as a wall material which gives lots of advantages. It could be functioning as an effective barrier towards environmental parameters including oxygen, light, and free radicals. In food industry, encapsulation using spray drying method is the most commonly used approach. Ahmed et al. [1] reported that encapsulated purple sweet potato flour resulted in a higher total phenolic content, antioxidant capacity, and water solubility index compared to non-encapsulated purple sweet potatoes flour. Research has been done on encapsulation effect using different types of wall materials such as maltodextrin, gum arabic, and gelatin. The advantages of encapsulation application include allowing easier handling, split the compound of the material which might react with one another, and providing a concentration for a uniform dispersion of an active agent.

In general, there are 3 types of wall material that have been used; it is classified as polysaccharides (maltodextrin, starch, and gum), lipids (stearic acid), and proteins (gelatin, casein, soy and wheat) [9]. Some studies used maltodextrin with different dextrose equivalents as an encapsulation agent. Researchers have reported that maltodextrin with low dextrose equivalent (DE) has excellent nutrient binding properties [10]. Furthermore, presence of maltodextrin as an encapsulating agent could alter the surface stickiness of low molecular weight sugars, which consequently might improve the quality of a product. Maltodextrin as encapsulation agent able to protect the ingredient from oxidation except a water-soluble material [2].

The objective of this study is to determine the effect of maltodextrin (MD, DE 4.0 - 7.0) concentration as a wall material and various microwave drying powers towards physicochemical properties of encapsulated purple sweet potato anthocyanin extract (PSPE). The effects of microwave drying power $(550 \mathrm{~W}$ and $330 \mathrm{~W})$ and maltodextrin (MD) concentration $(20 \%, 25 \%$, and $30 \%)$ were analysed for moisture content, water activity, colour, and total monomeric anthocyanin content (TMA). 


\section{Materials}

\section{Materials and Methods}

Purple sweet potatoes (PSP) were obtained from fresh market located in Skudai, Johor. PSP were then peeled, washed, and sliced before the pre-treatment and extraction process. The PSP extract was then filtered and centrifuged (MPW 352, Poland) at $5000 \mathrm{rpm}$ for 10 minutes to remove the fine suspended particles. PSP extract were then go through evaporation process using rotary evaporator (IKA RV 10, German) to achieve total solid $7^{\circ}$ Brix. The physicochemical properties of PSP anthocyanin extract subjected to encapsulation process were analysed. Maltodextrin (MD) with dextrose equivalent (DE) of 4.0 -7.0 was purchased from Sigma, Aldrich (German) used as wall materials.

\section{Encapsulation of purple sweet potato extract (PSPE)}

Encapsulation of PSPA extract were prepared as follows:50\% solution of maltodextrin (MD) were prepared with 70 ${ }^{\circ} \mathrm{C}$ distilled water under constant stirring at $120 \mathrm{rpm}$ for 1 hour and kept overnight at $4 \pm 2{ }^{\circ} \mathrm{C} .50 \%$ solution of wall material was then mixed with PSPA extract $\left(7^{\circ} \mathrm{Brix}\right)$. The mixtures were then homogenized at $30^{\circ} \mathrm{C}$ and subjected to microwave-assisted drying. Different proportions of wall/core materials were tested $(20 \%, 25 \%$ and $30 \%)$. A total of $25 \mathrm{~g}$ of each sample were weighed and exposed to the microwave radiation in the following operational condition: Microwave power $550 \mathrm{~W}$, and 330W, Drying time 300s. Samples were then ground, packed in the brown glass bottles, and stored over silica gel in desiccators at room temperature for further experiments.

\section{Moisture content and water activity}

Moisture content was carried out by weighing $3 \mathrm{~g}$ of samples and dried in an oven at $105{ }^{\circ} \mathrm{C}$ until it reached a constant weight. Water activity values were measured using water activity meter (4TE, USA). Temperature was maintained at $25^{\circ} \mathrm{C}$ during the test. Triplicate samples were analyzed and the mean was recorded.

\section{Total monomeric anthocyanin}

The total monomeric anthocyanin (TMA) was measured using the $\mathrm{pH}$-differential method by Giusti and Wrolstad [11], using two buffer systems; $0.025 \mathrm{M}$ potassium chloride buffer, $\mathrm{pH} 1.0$ and $0.4 \mathrm{M}$ sodium acetate buffer, $\mathrm{pH} 4.5$ [11]. Prepare two dilutions of PSPA using the two buffer systems (pH $1.0 \& \mathrm{pH} 4.5)$. Let the dilutions equilibrate for 15 minutes before measurement. Prolong standing times which may cause increase measured readings was avoided. Absorbance were measured for each dilution at $510 \mathrm{~nm}$ and $700 \mathrm{~nm}$. Wavelength of $700 \mathrm{~nm}$ is to correct for haze. Absorbance (A) of dilutions was calculated using the following equation 1:

$$
A=\left(A_{510}-A_{700}\right)_{\mathrm{pH} 1.0}-\left(A_{510}-A_{700}\right)_{\mathrm{pH} 4.5}
$$

TMA content of PSP powder was calculated as cyanidin-3-glycoside using equation 2 as follows:

$$
\text { Total Monomeric Anthocyanin Content }(\mathrm{mg} / \mathrm{L})=(\mathrm{A} \times \mathrm{MW} \times \mathrm{DF} \times 1000) /(\varepsilon \times 1)
$$

where MW is the molecular weight, DF is the dilution factor, and $\varepsilon$ is the molar absorptivity.

\section{Colour}

For the colour analysis, measurement of CIE L*(lightness), $a^{*}$ (red to green), $b^{*}$ (yellow to blue) values were done using Konica Minolta CR-400 Colorimeter. The samples were placed in glass plates and directly measured. Triplicate samples were analyzed and the mean was recorded.

\section{Statistical analysis}

In this research, multiple comparison methods (Tukey) along with One-way ANOVA were used to determine the statistical significance of the data $(\mathrm{p}<0.05)$. 


\section{Alyani et al: PHYSICOCHEMICAL PROPERTIES OF ENCAPSULATED PURPLE SWEET POTATO EXTRACT; EFFECT OF MALTODEXTRIN CONCENTRATION, AND MICROWAVE DRYING POWER}

\section{Physicochemical properties of PSPA extract prior drying}

\section{Results and Discussion}

Table 1 shows the physicochemical properties of purple sweet potato extract (PSPE) subjected to encapsulation process. Total soluble solid of PSPE was fixed at $7.0^{\circ}$ Brix before mixing it with maltodextrin $50 \%$ solution. The variety of total solid contents of feed prior to drying might affect the drying efficiency.

Table 1. Physicochemical properties of PSPE subjected to encapsulation process

\begin{tabular}{lc}
\hline Parameter & Value \\
\hline Total Soluble solid (Brix) & 7.0 \\
$\mathrm{pH}$ & $6.43 \pm 0.01$ \\
Monomeric Anthocyanin content (mg/L) & 121.07 \\
Color Parameter & \\
$\mathrm{L}^{*}$ & $20.5 \pm 0.4$ \\
$\mathrm{a}^{*}$ & $26.5 \pm 1.2$ \\
$\mathrm{~b}^{*}$ & $-3.6 \pm 0.1$ \\
$\mathrm{C}^{*}$ & $26.3 \pm 0.1$ \\
$\mathrm{H}$ & $352.0 \pm 0.2$ \\
\hline
\end{tabular}

All data are the mean of triplicate measurements \pm standard deviation values

\section{Moisture content and water activity}

Moisture content is important in determining the amount of total water present in a product and can be used as a process monitoring. Lower moisture content limits the ability of water to act as plasticizer, and to prevent or reduce the capability of caking and agglomeration issue. The total solid content of feed prior to drying will affect the final moisture content of product. The addition of MD to the extract prior to drying process consequently increased the total solid content and reduced the amount of water for evaporation.

In this study, PSPA were encapsulated with maltodextrin (DE: 4.0 - 7.0).MD concentration of $20 \%, 25 \%$ and $30 \%$ were used and exposed to the microwave drying power of $330 \mathrm{~W}$ and $550 \mathrm{~W}$. The results showed that the moisture content of encapsulated PSPE decreased when the maltodextrin added was increased. Encapsulated PSPE moisture contents are ranged from $3.76 \pm 0.02$ to $4.25 \pm 0.04 \%$. Significant decreased $(\mathrm{p}<0.05)$ of moisture content results were showed at $20 \%$ and $30 \%$ of maltodextrin added at both $550 \mathrm{~W}$ and $330 \mathrm{~W}$ microwave power level. Researcher proves that additional MD percentage resulted in an increased of total solid which causing reduction of total moisture for evaporation $[10,12]$.

Shelf life of a powder product is greatly affected by its water activity value. Water activity value ranges from 0.20 0.40 for any dried foods is considered as microbiological stable [12] which might prolong the shelf life of product. Results from Table 2 show that encapsulated PSPE are in the ranges of $0.2588 \pm 0.0049$ to $0.3912 \pm 0.0132$. Increasing of maltodextrin significantly $(p<0.05)$ decreased the water activity value. 
Table 2. Effect of maltodextrin (MD) concentration and microwave power level on total monomeric anthocyanin content (TMA), of encapsulated PSPE

\begin{tabular}{lcccc}
\hline $\begin{array}{l}\text { Microwave } \\
\text { Power } \\
\text { (W) }\end{array}$ & $\begin{array}{c}\text { Maltodextrin } \\
\text { Concentration } \\
(\%)\end{array}$ & $\begin{array}{c}\text { Moisture } \\
\text { Content } \\
(\%)\end{array}$ & $\begin{array}{c}\text { Water } \\
\text { Activity }\end{array}$ & $\begin{array}{c}\text { TMA } \\
(\mathbf{m g} / \mathbf{L})\end{array}$ \\
\hline & 20 & $3.98 \pm 0.01^{\mathrm{a}}$ & $0.3428 \pm 0.0177^{\mathrm{a}}$ & $385.93 \pm 10.81^{\mathrm{a}}$ \\
550 & 25 & $3.83 \pm 0.01^{\mathrm{b}}$ & $0.2924 \pm 0.0079^{\mathrm{b}}$ & $285.73 \pm 5.24^{\mathrm{b}}$ \\
& 30 & $3.76 \pm 0.02^{\mathrm{b}}$ & $0.2636 \pm 0.0079^{\mathrm{c}}$ & $263.53 \pm 7.66^{\mathrm{b}}$ \\
& 20 & $4.25 \pm 0.04^{\mathrm{c}}$ & $0.3912 \pm 0.0132^{\mathrm{a}}$ & $419.28 \pm 10.89^{\mathrm{a}}$ \\
330 & 25 & $4.14 \pm 0.04^{\mathrm{d}}$ & $0.3042 \pm 0.0126^{\mathrm{b}}$ & $337.11 \pm 8.47^{\mathrm{c}}$ \\
& 30 & $3.95 \pm 0.01^{\mathrm{d}}$ & $0.2588 \pm 0.0049^{\mathrm{c}}$ & $314.86 \pm 6.41^{\mathrm{c}}$ \\
\hline
\end{tabular}

All data are the mean of triplicate measurements \pm standard deviation values. a, b, c, means with different letter(s) in the same column differed significantly $(\mathrm{p}<0.05)$.

\section{Total monomeric anthocyanin content}

Total monomeric anthocyanin (TMA) of encapsulated PSPE has been measured and the results are shown in Table 2. TMA of PSPE range between $263.53 \pm 7.66$ to $419.28 \pm 10.89 \mathrm{mg} / \mathrm{L}$. PSPA with $20 \%$ concentration give the highest TMA at both microwave drying power $330 \mathrm{~W}$ and $550 \mathrm{~W}$, with $385.93 \pm 10.81 \mathrm{mg} / \mathrm{L}$ and $419.28 \pm 10.89$ $\mathrm{mg} / \mathrm{L}$, respectively. The addition of MD at $20 \%, 25 \%$ and $30 \%$ and different microwave power $(550 \mathrm{~W}$ and $330 \mathrm{~W}$ ) was not significantly affect the TMA content of microwave-assisted encapsulated PSPE. However, a significant ( $p$ $<0.05$ ) anthocyanin reduce can be seen between $20 \%$ and $30 \%$ of maltodextrin addition. A larger range of maltodextrin concentration and different drying time can be studied to see the significant changes of TMA. An optimum drying parameter and formulation of the encapsulation process could be achieved. In this study, time factor could be included because short drying time may cause insufficient drying and longer drying time may degrade the anthocyanin content in the capsule [5].

\section{Colour}

The colour $\left(\mathrm{L}^{*}, \mathrm{a}^{*}\right.$, and $\mathrm{b}^{*}$ values) values of the microwave-assisted encapsulated PSPA were measured with a Minolta CR-400 Colorimeter, Japan and the results were expressed in accordance with the CIE Lab. The L* value, is a measure of lightness which ranges between 0 and 100. Addition of wall material might cause the increases of L* values [9].

Table 3 shows a significance difference in $\mathrm{L}^{*}$ values between control and encapsulated PSPA extract. L* value of encapsulated PSPE was increased due to the presence of maltodextrin, since the maltodextrin initially has white colour $\left(L^{*}=98.18 \pm 0.15\right)$. Furthermore, a significant difference of $L^{*}$ values was found with the increasing of maltodextrin content. This is supported by Ahmed et al. [1] where the increasing of maltodextrin concentration causing the $\mathrm{L}^{*}$ value of spray dried purple sweet potato flour increased.

The redness $\left(+\mathrm{a}^{*}\right)$ of encapsulated PSPE were significantly reduced with the increased of maltodextrin concentration while the blueness $\left(-b^{*}\right)$ is not significantly affected. Microwave power was not significantly affect the value for both redness $\left(+a^{*}\right)$ and blueness $\left(-b^{*}\right)$. 


\section{Alyani et al: PHYSICOCHEMICAL PROPERTIES OF ENCAPSULATED PURPLE SWEET POTATO EXTRACT; EFFECT OF MALTODEXTRIN CONCENTRATION, AND MICROWAVE DRYING POWER}

Table 3. Colometric results of encapsulated PSPE at different maltodextrin concentrations and microwave power levels

\begin{tabular}{lcccc}
\hline $\begin{array}{l}\text { Microwave Power } \\
\text { (W) }\end{array}$ & $\begin{array}{l}\text { MD } \\
(\mathbf{\%})\end{array}$ & $\mathbf{L}^{*}$ & $\mathbf{a}^{*}$ & $\mathbf{b}^{*}$ \\
\hline $\begin{array}{l}\text { Non-encapsulated } \\
\text { (control) }\end{array}$ & & $20.1 \pm 0.35$ & $26.5 \pm 1.2$ & $-3.55 \pm 0.05$ \\
550 & 20 & $49.83 \pm 0.21^{\mathrm{a}}$ & $35.30 \pm 0.17^{\mathrm{a}}$ & $-10.6 \pm 0.20^{\mathrm{a}}$ \\
& 25 & $52.7 \pm .0 .63^{\mathrm{b}}$ & $33.47 \pm 0.70^{\mathrm{b}}$ & $-10.3 \pm 0.21^{\mathrm{b}}$ \\
& 30 & $54.63 \pm 0.67^{\mathrm{c}}$ & $32.37 \pm 0.75^{\mathrm{c}}$ & $-10.7 \pm 0.26^{\mathrm{a}}$ \\
330 & 20 & $50.7 \pm 0.37^{\mathrm{d}}$ & $34.00 \pm 0.56^{\mathrm{d}}$ & $-10.3 \pm 0.17^{\mathrm{c}}$ \\
& 25 & $55.43 \pm 0.61^{\mathrm{b}}$ & $33.17 \pm 0.71^{\mathrm{b}}$ & $-10.6 \pm 0.10^{\mathrm{b}}$ \\
& 30 & $55.73 \pm 0.84^{\mathrm{c}}$ & $31.23 \pm 0.47^{\mathrm{e}}$ & $-10.8 \pm 0.00^{\mathrm{a}}$ \\
\hline
\end{tabular}

All data are the mean of triplicate measurements \pm standard deviation values. a, b, c, means with different letter(s) in the same column differed significantly $(\mathrm{p}<0.05)$

\section{Conclusion}

Maltodextrin (MD, $\mathrm{DE}=4.0$ - 7.0) is effective as drying aid for encapsulation of PSPE. The addition of various MD concentrations on physicochemical properties of encapsulated PSPE was investigated in this study. The results showed that MD concentrations at $20 \%$ and $30 \%$ significantly $(\mathrm{p}<0.05)$ reduced moisture content, water activity, and TMA content of encapsulated PSPE. Furthermore, a significant difference of $\mathrm{L}^{*}$ values was found with the increasing content of maltodextrin. However, microwave power levels of $550 \mathrm{~W}$ and $330 \mathrm{~W}$ was not significantly affecting the TMA, moisture content, water activity, and colour value of microwave-assisted PSPA. This could be enhanced by widening the range of study parameters and including drying time factor so that an optimum parameter of encapsulation process could be determined.

\section{Acknowledgement}

The authors would like to thank Universiti Teknologi Malaysia (UTM), Ministry of Higher Education (MOHE), and Research Management Centre (RMC), UTM for their financial support of this work through the project number Q.J130000.3009.00M65.

\section{References}

1. Ahmed, M., Akter, M. S. and Eun, J. B. (2010). Impact of $\alpha$-amylase and maltodextrin on physicochemical, functional and antioxidant capacity of spray-dried purple sweet potato flour. Journal of the Science of Food and Agriculture, 90(3): 494-502.

2. Aishah, B., Nursabrina, M., Noriham, A., Norizzah, A. R. and Mohamad Shahrimi, H. (2013). Anthocyanins from Hibiscus sabdariffa, Melastoma malabathricum and Ipomoea batatas and its color properties. International Food Research Journal, 20(2): 827-834.

3. Li, J., Li, X. D., Zhang, Y., Zheng, Z. D., Qu, Z. Y., Liu, M., Zhu, S. H., Liu, S., Wang, M. and Qu, L. (2013). Identification and thermal stability of purple-fleshed sweet potato anthocyanins in aqueous solutions with various $\mathrm{pH}$ values and fruit juices. Food Chemistry, 136(3): 1429-1434.

4. Choi, I., Lee, J. Y., Lacroix, M. and Han, J. (2017). Intelligent pH indicator film composed of agar/potato starch and anthocyanin extracts from purple sweet potato. Food Chemistry, 218 (Supplement C): 122-128.

5. Zaidel, D. N. A., Aqilah, N. and Mohd, Y. M. (2015). Efficiency and thermal stability of encapsulated anthocyanins from red dragon fruit (Hylocereus polyrhizus (Weber) Britton \& Rose ) using microwave-assisted technique. Chemical Engineering Transactions, 43: 127-132.

6. Mohd Nawi, N., Muhamad, I. I. and Mohd Marsin, A. (2015). The physicochemical properties of microwaveassisted encapsulated anthocyanins from Ipomoea Batatas as affected by different wall materials. Food Science and Nutrition, 3(2): 91-99. 
7. Haghi, A. K. and Amanifard, N. (2008). Analysis of heat and mass transfer during microwave drying of food products. Brazilian Journal of Chemical Engineering, 25: 491-501.

8. Ahmed, M., Akter, M. S., Lee, J. C. and Eun, J. B. (2010). Encapsulation by spray drying of bioactive components, physicochemical and morphological properties from purple sweet potato. LWT - Food Science and Technology, 43(9): 1307-1312.

9. Peng, Z., Li, J., Guan, Y. and Zhao, G. (2013). Effect of carriers on physicochemical properties, antioxidant activities and biological components of spray-dried purple sweet potato flours. LWT - Food Science and Technology, 51(1): 348-355.

10. Quek, S. Y., Chok, N. K. and Swedlund, P. (2007). The physicochemical properties of spray-dried watermelon powders. Chemical Engineering and Processing: Process Intensification, 46(5): 386-392.

11. Giusti, M. M. and Wrolstad, R. E. (2001). Characterization and measurement of anthocyanins by UV-visible spectroscopy. Current Protocols in Food Analytical Chemistry, John Wiley \& Sons, Inc, Hoboken, USA.

12. Caliskan, G. and Dirim, S. N. (2016). The effect of different drying processes and the amounts of maltodextrin addition on the powder properties of sumac extract powders. Powder Technology, 287 (Supplement C): 308314. 